\title{
Outline of an intellectual biography of Professor Waldemar Dutkiewicz (1939-2007)
}

\section{Zarys biografii intelektualnej profesora Waldemara Dutkiewicza (1939-2007)}

\author{
Paweł Grzybek \\ Department of Education History and Organization, Institute of Pedagogy and Psychology, Faculty of Pedagogy and Art, \\ Jan Kochanowski University, Kielce, Poland \\ Head of the Department: Prof. UJK Ewa Kula PhD
}

Key words: Waldemar Dutkiewicz, auxology, pedagogy, biography.

Słowa kluczowe: Waldemar Dutkiewicz, auksologia, pedagogika, biografia.

\begin{abstract}
The date of February 19, 2017 has marked the $10^{\text {th }}$ death anniversary of Prof. Waldemar Dutkiewicz, who was an outstanding pedagogue, organiser of didactic and educational work, great social worker, and above all an eminent scholar. Professor Dutkiewicz died suddenly on February 19, 2007, still with his full creative forces. The professor was born on June 2, 1939 in Rivne, in Volhynia. In the period 1957-1963 he studied at the School of Physical Education in Krakow. He completed his pedagogical studies in 1970 at the Higher School of Pedagogy in Krakow. In 1973 he obtained a doctoral degree in physical education. His doctorate in pedagogy was publicly defended in 1982. At the Academy of Physical Education in Warsaw he received his Doctor of Letters (habilitation) degree in the field of physical education in 1986. By a decision of the President of the Republic of Poland of August 22, 1995 he was awarded the title of Professor. Due to his studies and didactic work the heritage of Professor Dutkiewicz is composed of two parts: auxological and pedagogical.
\end{abstract}

\section{Streszczenie}

19 lutego 2017 r. minęła 10. rocznica śmierci prof. Waldemara Dutkiewicza, który był znakomitym pedagogiem, organizatorem pracy dydaktyczno-wychowawczej, wielkim społecznikiem, a przede wszystkim wybitnym naukowcem. Profesor Dutkiewicz zmarł nagle 19 lutego 2007 r. w pełni sił twórczych. Urodził się 2 czerwca 1939 r. w Równem na Wołyniu. W latach 1957-1963 studiował w Wyższej Szkole Wychowania Fizycznego w Krakowie. Studia pedagogiczne ukończył w 1970 r. w Wyższej Szkole Pedagogicznej w Krakowie. W 1973 r. uzyskał stopień naukowy doktora nauk wychowania fizycznego. Doktorat z pedagogiki obronił w 1982 r. na Akademii Wychowania Fizycznego w Warszawie, habilitował się w zakresie nauk o kulturze fizycznej w 1986 r. Postanowieniem prezydenta Rzeczypospolitej Polskiej z dnia 22 sierpnia 1995 r. otrzymał tytuł naukowy profesora. Spuścizna prof. Dutkiewicza obejmuje dwa nurty - auksologiczny i pedagogiczny, będące konsekwencją jego studiów i pracy dydaktycznej.

\section{Introduction}

The year 2017 the marks $10^{\text {th }}$ anniversary of the death of Professor Waldemar Dutkiewicz, who was an outstanding pedagogue, organiser of didactic and educational work, great social worker, and above all an eminent scholar. Professor Dutkiewicz died suddenly on February 19, 2007, still with his full creative forces. At the funeral mass Marian Florczyk, Catholic Assisting Bishop of Kielce, said: "One cannot compare the feeling of emptiness. However, this one is of considerable significance. It proves that the person who passed away left behind traces of good, friendship, knowledge, kindness (...)" [1]. It is hard to reject this statement. The Professor's former doctoral student
Monika Szpringer recollected: "Professor Waldemar Dutkiewicz was an outstanding man. Not only a Master and Teacher, but most of all a friend. He was looking for the best solutions for people, and it was presumably his most prominent feature. He was always with young people, his employees, he had time for us. He was good to people (...)" [2]. Waldemar Dutkiewicz was born in 1939 in Rivne, in the region of Volhynia (now Ukraine). In the period 1957-1963 he studied at the School of Physical Education in Krakow. He completed his pedagogical studies in 1970 at the Higher School of Pedagogy in Krakow. In 1973 he obtained a doctoral degree in physical education. His doctorate in pedagogy was publicly defended in 1982. In 1986 
at the Academy of Physical Education in Warsaw he received his Doctor of Letters degree (habilitation) in the field of physical education. By a decision of the President of the Republic of Poland of August 22, 1995 he was awarded the title of Professor. Due to his studies and didactic work, the heritage of Professor Dutkiewicz is composed of two parts: auxological and pedagogical.

\section{Auxology}

Proper and optimal growth of young people was of great concern to Waldemar Dutkiewicz, and it inspired him to turn into auxology. He was interested in somatic and motor changes in the youth population of Poland, acceleration development and secular trends in increased height, and environmental conditions for physical and mental growth [3]. Dutkiewicz carefully analysed the growth of children and adolescents in the region of Kielce and described children from rural areas of the region [4]. Some works of Dutkiewicz focusing on the issues in question are worth mentioning here. In 1980 he published the book "Różnice środowiskowe w rozwoju biologicznym i sprawności ruchowej dzieci w okresie dorastania" [5], which described development of somatic and motor features in a particular age group in connection with environmental conditions. The author described selected elements of personality, intellect, temperament, and neuroticism. He had two goals - the first, theoretical, to focus on relations between elements affecting development and to find biological and social cause-and-effect dependencies. The second goal, practical, was to develop guidelines for optimal conditions for children reaching puberty [5]. Another work, published in 1985, was "Zmiany w procesach rozwoju biologicznego i sprawności fizycznej młodzieży w świetle poprawy warunków bytowych" [6]. This book verified ideas and views of that time concerning causes and consequences of changes in growth and maturation, and defined social and demographic changes. It presented secular changes and acceleration of morphological development and puberty as well as faster mental and social development with environmental differences. It also contained results of studies on changes in fitness of the young generation [7]. In 1987 Waldemar Dutkiewicz published another book "Znaczenie wybranych wskaźników rozwoju fizycznego, ocen szkolnych i warunków socjalno-bytowych w przystosowaniu szkolnym uczniów" [8]. From numerous factors affecting students' acceptance among his classroom peers (one of the elements of school adaptation according to Waldemar Dutkiewicz), the author decided to analyse social and living conditions, school grades, and physical growth. The book is composed of three chapters, the first describing social adaptation of pupils to school conditions. The second one presents the way the studies were organised, and the third - the results. The author defined anthropometric, sociometric, and pedagogical methods that make it possible to describe the differences between pupils with high and low social positions among their classroom peers. Moreover, he characterised social and biological conditions, sociometric status, and pedagogical consequences of association with outcast, tolerated, or leading pupils [9]. Published in 1990 "Dziecko wiejskie" [10] discusses selected problems of children from rural areas in the mid 1980s in comparison to their peers from urban populations. The author identified psychological, social, and biological development, fitness, and health of children from rural areas. He suggested solutions for discrepancies between children form rural and urban areas as well as some guidelines for schools, problems of care, burden, free time, and relaxation of children from rural areas. Waldemar Dutkiewicz also paid attention to the goals of families, kindergartens, and schools, which should focus on neutralising differences in children development [11]. One year later the Professor published another book entitled "Zjawiska trendów sekularnych i akceleracji rozwoju dzieci i młodzieży na Kielecczyźnie" [12], in which he discussed two phenomena resulting from adaptation to external conditions of development. The first one is a secular trend connected to intergenerational changes, which lead to increasingly higher values of the final development features. The second phenomenon is acceleration of development, which refers to changes within the lifespan of one generation. It also leads to both faster growth to a particular body size and earlier puberty [13]. Waldemar Dutkiewicz began with the presentation of secular trends and acceleration of development and puberty of children and youth from the professional literature. Then he characterised physical development of children and adolescents from the region of Kielce and its surrounding areas according to available studies and described changes in the development and puberty of children and adolescents in the region in question in the twentieth century. In 2004, under the influence of diagnosis and evaluation of processes connected to physical education at school and the fact that teachers were waiting for assistance in this regard (he worked for the Voivodeship Commission of Professional Specialisation for Teachers of Physical Education and had considerable experience in diagnosing in physical education during postgraduate studies in physical education), Waldemar Dutkiewicz published a methodical and methodological book "Diagnoza i ewaluacja w wychowaniu fizycznym" [14]. It introduces theoretical and practical aspects of complex problems connected with recognition and valuation to physical education teachers. The goal of W. Dutkiewicz was to provide physical education teachers with theoretical knowledge of diagnosing and practical guidelines in order to develop their 
competences. Apart from theoretical background he presented the rules and conditions for organisation of diagnosing and evaluation in practice. The book seems to be composed of two parts: methodological and practical. The first one discusses the theory, use, and application of diagnosing with its procedures and structure. The second presents selected practical diagnosing methods and techniques as well as general patterns and rules [15]. In 2004 Grażyna Nowak-Starz, Elżbieta Cieśla and Waldemar Dutkiewicz, members of the Department for Studies on Development Age from the Institute of Medical Education of the Świętokrzyska Academy in Kielce (now the Jan Kochanowski University in Kielce), focused on an important (theoretically and practically) issue of children's physical development and published a book "Normy i wskaźniki rozwoju somatycznego i motorycznego dzieci i młodzieży z Kielecczyzny” [16]. Their work allowed for a comprehensive description including 18 somatic features as well as five motor skills identified during the examination of 5632 children from the region of Kielce. It describes the physical development of that time and it is of cognitive value. First chapters provide information on standards and their use in diagnosing children's development, sexual dimorphism, and acceleration and sensitivity of development. In the empirical part the book the results of the studies were presented, which may be useful for any persons interested in auxology, paediatricians, people working for school health services, physical education teachers, medicine and pedagogy students, and parents [17]. With his concern about fitness of future generations W. Dutkiewicz and Monika Szpringer published "Społeczna akceptacja dla ryzykownych zachowań uczniów” [18], in which they developed the diagnosis of social acceptance for risky behaviour of pupils. The first chapters describe a school class as an organised social system and as a social and educational environment, and they discuss social adaptation of pupils to their school conditions. The authors also presented social problems connected with the use of intoxicating substances by young persons. The main problem of empirical work is the question of self-acceptance among pupils who take intoxicating substances. The study was based on the data obtained from 1811 participants - young persons from lowersecondary schools (gimnazjum) and older. The last part of the book presented rationale, necessity, and efficiency conditions of school programs of preventive treatment. The authors compared preventive treatment at school with other European countries. They analysed aspects of good development and introduction of school preventive treatment with critical analysis of selected preventive programs from schools [19].

Apart from the above selection of works Waldemar Dutkiewicz was also the author of over 100 papers, re- views, and numerous conference presentations. His written heritage combines deep knowledge with experience in the fields of auxology and pedagogy.

\section{Pedagogy}

Works on pedagogy written by Waldemar Dutkiewicz focus on two areas. The first concentrates on studies on teaching profession, education, and teachers' development in the region of Kielce. Waldemar Dutkiewicz knew this from his own experience because after his graduation he became a teacher in a primary school in Kazimierza Wielka. One year later he was promoted to the position of a deputy headmaster, and then headmaster. In the meantime, he was also a head of self-education groups for physical education teachers and school headmasters at the Methodical Centre as well as a chairman of regional conferences of the Poviat Board of the Polish Teachers' Union - ZNP. In 1974 he started working for the Teachers Training and Education Research Institute in Kielce as an assistant professor (research and teaching fellow). For 5 years from 1975 he was deputy head of the institute responsible for research and science and the head of Research Group. Then he moved to the Teacher Training College in Kielce to become an assistant professor at the Institute of Pedagogy. As a doctor and then professor he gave considerable support to young scholars. Professor Grażyna Nowak-Starz, D.Litt.: "It is great when you have a Master with such immense knowledge wishing to teach others. He gave us - his students - not only theory, he also encouragement to search on our own; he inspired us all his life. He was an open-minded person with a magnetic personality (...). He showed us problems we may face working with pupils and their possible solutions. He was always with the young. He had a great ability to attract people" [20]. He is reported to have eagerly shared his knowledge and experience, both scientific and didactic. He was an educator and advisor to five students who received doctoral degrees:

1. Grażyna Nowak-Starz

2. Aldona Kopik

3. Sławomir Koziej

4. Monika Szpringer

5. Stanisław Hojda

He supervised about 500 master's theses, mainly on children and adolescents in the region of Kielce. Moreover, he was also a reviewer in doctoral examination procedures and head of a doctoral seminar that gained enormous popularity among students and respect from his fellow scholars.

The second area of interest for W. Dutkiewicz was methodology of pedagogical and anthropological studies. One of the most influential works was published in the 1993 methodological guide for students writing master's theses of empirical nature in pedagogy. It had several editions and was frequently updated 
due to new needs. Its 2001 the edition was entitled "Podstawy metodologii badań do pracy magisterskiej i licencjackiej z pedagogiki” [21]. Dutkiewicz claimed that the master's thesis had two main goals in academic teaching: didactic - expanding knowledge of young people in a specific field, and scholarly - developing methodological skills, exploring professional literature and scientific heritage in a particular discipline. Students should combine their knowledge from their academic education with theoretical rules of scientific research and analysis of collected materials, and draw conclusions. Because he spent many years supervising students theses, Dutkiewicz gained the necessary knowledge on writing about the problems of young scholars. In order to assist them he wrote a step-bystep guide of writing a good diploma thesis. The book is composed of seven chapters, with the first devoted to methodological background of pedagogical studies. The second chapter presents the most frequent types of research, and the next discusses theoretical and practical background of diagnosing research and educational diagnosis. The next chapter describes particular stages of scientific research from the concept through defining subjects, goals, problems and hypotheses, notions, selection of variables and parameters, as well as techniques, methods, time span, place, and the scope of the research itself. The next chapter deals with processing of collected data. The penultimate part discusses text preparation, its layout, footnotes, bibliography, and proofreading marks. The last chapter presents basic evaluation criteria of the thesis. The annex contains regulations for educational institutions where research will be carried out [22].

\section{Conclusions}

Ten years ago, the academic community lost an outstanding scholar, wholeheartedly devoted to his studies, accurate, and persevering. A hardworking, disciplined wise man and teacher, a real master, who always encouraged his students with the following sayings:

- "Learn to use the time you have, it will not be better.

- Do not look at others, work as much as you can instead.

- Do not be discouraged by criticism, it should motivate you to work harder.

- Waiting for compliments from others may be a waste of precious time.

- Become a master of your profession.

- Do not spread yourself too thin and do not take each and every offer you get.

- Do not be fooled by financial offers, being a scholar will not make you a millionaire, but it may bring you satisfaction if are faithful to it" [23].

In his life Waldemar Dutkiewicz tried to follow these rules and recommended them to his students, colleagues, and scholar friends.

\section{Conflict of interest}

The author declares no conflict of interest.

\section{References}

1. Dotyk pustki. Głos Akademicki 2007; 1: 2-4.

2. Stępień K. Życie, działalność dydaktyczno-organizacyjna oraz twórczość naukowa prof. dr hab. Waldemara Dutkiewicza (1939-2007). Master's Thesis, Kielce 2014; 68.

3. Badania naukowe w Wyższej Szkole Pedagogicznej w Kielcach w latach 1969-1989. Massalski A (ed.). Wyższa Szkoła Pedagogiczna, Kielce 1991; 159-74.

4. Archiwum Uniwersytetu Jana Kochanowskiego w Kielcach. Przewęda R. Recenzja dorobku naukowego prof. dr hab. W. Dutkiewicza, 22.01.1995 r., Sygn. 1583/158, p. 1-6. Sprawozdanie z działalności naukowo-badawczej Instytutu wraz ze sprawozdaniami naukowymi pracowników za 1995 r. Instytut Pedagogiki Wczesnoszkolnej 1996.

5. Dutkiewicz W. Różnice środowiskowe w rozwoju biologicznym i sprawności ruchowej dzieci w okresie dorastania. Instytut Kształcenia Nauczycieli i Badań Oświatowych, Kielce 1980.

6. Dutkiewicz W. Zmiany w procesach rozwoju biologicznego i sprawności fizycznej młodzieży w świetle poprawy warunków bytowych. Wyższa Szkoła Pedagogiczna, Kielce 1985.

7. Archiwum Uniwersytetu Jana Kochanowskiego w Kielcach. Milcerowa H. Recenzja wydawnicza rozprawy doc. Waldemara Dutkiewicza p.t. „Zmiany sekularne rozwoju i sprawności fizycznej młodzieży w świetle czynników środowiska społecznego". Sygn. 969/45: 1-9.

8. Dutkiewicz W. Znaczenie wybranych wskaźników rozwoju fizycznego, ocen szkolnych i warunków socjalno-bytowych w przystosowaniu szkolnym uczniów. Wyższa Szkoła Pedagogiczna, Kielce 1987.

9. Archiwum Uniwersytetu Jana Kochanowskiego w Kielcach. Kopczyńska-Sikorska J. Recenzja pracy Waldemara Dutkiewicza p.t. „Rozwój fizyczny a przystosowanie szkolne”. Sygn. 986/24: 1-4.

10. Dutkiewicz W. Dziecko wiejskie. Wyższa Szkoła Pedagogiczna, Kielce 1990.

11. Archiwum Uniwersytetu Jana Kochanowskiego w Kielcach. Łopatkowa M. Recenzja pracy Waldemara Dutkiewicza pt. „Dziecko wiejskie”. Sygn. 1080/43: 1-7.

12. Dutkiewicz W. Zjawiska trendów sekularnych i akceleracji rozwoju dzieci i młodzieży na Kielecczyźnie. Wyższa Szkoła Pedagogiczna, Kielce 1991.

13. Archiwum Uniwersytetu Jana Kochanowskiego w Kielcach. Przewęda R. Recenzja wydawnicza pracy p. Waldemara Dutkiewicza pt. „Zjawiska trendów sekularnych i akceleracji rozwoju dzieci i młodzieży na Kielecczyźnie”. Sygn. 1080/38: 1-6.

14. Dutkiewicz W. Diagnoza i ewaluacja w wychowaniu fizycznym. Wydawnictwo Akademii Świętokrzyskiej, Kielce 2004.

15. Archiwum Uniwersytetu Jana Kochanowskiego w Kielcach. Bukowiec M. Recenzja pracy prof. Waldemara Dutkiewicza p.t. „Diagnoza i ewaluacja w wychowaniu fizycznym”. Sygn. 2066/29: 1-4.

16. Dutkiewicz W, Nowak-Starz G, Cieśla E. Normy i wskaźniki rozwoju somatycznego i motorycznego dzieci i młodzieży z Kielecczyzny. Wydawnictwo Stachurski, Kielce 2004 . 
17. Dutkiewicz W, Nowak-Starz G, Cieśla E. Normy i wskaźniki rozwoju somatycznego i motorycznego dzieci i młodzieży z Kielecczyzny. Wydawnictwo Stachurski, Kielce 2004; 7-8.

18. Dutkiewicz W, Szpringer M. Społeczna akceptacja dla ryzykownych zachowań uczniów. Zakład Poligraficzno-Wydawniczy MAGRAF, Kielce 2007.

19. Franczak K, Dutkiewicz W, Szpringer M. Społeczna akceptacja dla ryzykownych zachowań uczniów. Kielce 2007. Problemy Opiekuńczo Wychowawcze 2008; 4: 61-2.

20. Stępień K. Życie, działalność dydaktyczno-organizacyjna oraz twórczość naukowa prof. dr hab. Waldemara Dutkiewicza (1939-2007). Master's Thesis, Kielce 2014; 68.

21. Dutkiewicz W. Podstawy metodologii badań do pracy magisterskiej i licencjackiej z pedagogiki. Wydawnictwo Stachurski, Kielce 2001.

22. Dutkiewicz W. Podstawy metodologii badań do pracy magisterskiej i licencjackiej z pedagogiki. Wydawnictwo Stachurski, Kielce 2001; 5-7.

23. A documentary movie. Prof. dr hab. Waldemar Dutkiewicz - nowator pedagogiczny (wspomnienia). Jurkiewicz E, Kowalski M, Sojda G, Adamczyk M. Kielce 2007.

\section{Address for correspondence:}

Paweł Grzybek

Department of Education History and Organization

Institute of Pedagogy and Psychology

Faculty of Pedagogy and Art

Jan Kochanowski University

ul. Krakowska 11, 25-029 Kielce, Poland

Phone: +48 793926300

E-mail: pawelgrzybek@vp.pl 